\title{
Artikel
}

\section{General Comment No. 24 - nieuw elan voor het jeugdstrafrecht?}

\author{
Over leeftijdsgrenzen, 'diversion' en de bredere implicaties voor het jeugdstrafrecht
}

Mr. dr. Y.N. (Yannick) van den Brink en prof. mr. E.M. (Isabeth) Mijnarends*

\section{Inleiding ${ }^{1}$}

In het afgelopen jaar hebben zich meerdere belangwekkende ontwikkelingen voorgedaan op het gebied van internationale en Europese kinderrechten en het jeugdstrafrecht. Zo is in juni 2019 de Richtlijn (EU) 2016/800 inzake procedurele waarborgen voor kinderen in strafprocedures in werking getreden en bij wet geimplementeerd in het Nederlandse jeugdstrafrecht. ${ }^{2}$ Voorts is in november 2019 de United Nations Global Study on Children Deprived of Liberty gepubliceerd,

Mr. dr. Y.N. van den Brink is universitair docent Jeugdrecht en Strafrecht aan de Universiteit Leiden en thans als Rubicon research fellow verbonden aan de University of Cambridge, Institute of Criminology (Verenigd Koninkrijk). Prof. mr. E.M. Mijnarends is landelijk coördinerend jeugdofficier bij het Openbaar Ministerie en tevens bijzonder hoogleraar Jeugdstrafrecht aan de Universiteit Leiden en heeft op persoonlijke titel als coauteur bijgedragen aan dit artikel. De auteurs danken mr. T. (Tim) Grootenhuis voor zijn ondersteuning bij het praktijkonderzoek en de respondenten voor hun medewerking.

1. Deze bijdrage presenteert de bevindingen van een praktijkonderzoek naar de mogelijke implicaties van General Comment No. 24 voor het Nederlandse jeugdstrafrecht en is gebaseerd op een lezing van Van den Brink tijdens het symposium '30 jaar IVRK', dat plaatsvond op 15 november 2019 in het Vredespaleis te Den Haag. Deze bijdrage bouwt tevens voort op een eerdere bijdrage van de auteurs, waarin de mogelijke implicaties van General Comment No. 24 voor vrijheidsbeneming in het Nederlandse jeugdstrafrecht zijn onderzocht: Y.N. van den Brink \& E.M. Mijnarends, 'General Comment No. 24 en het Nederlandse jeugdstrafrecht. Reflecties op vrijheidsbeneming van minderjarigen', in: E.C.C. Punselie e.a. (red.), 30 jaar IVRK, Deventer: Kluwer 2020 (nog te verschijnen).

2. Wet van 15 mei 2019, Stb. 2019, 180/181. waarin het wereldwijde fenomeen van vrijheidsbeneming van kinderen in kaart is gebracht en aanbevelingen worden gedaan over hoe deze praktijk meer in lijn kan worden gebracht met internationale kinderrechten. Twee maanden eerder, op 18 september 2019, heeft het Kinderrechtencomité van de Verenigde Naties General Comment No. 24 gepubliceerd over kinderrechten in het jeugdstrafrecht. ${ }^{3}$ In dit nieuwe General Comment, dat het eerdere General Comment No. 10 (2007) vervangt, ${ }^{4}$ schetst het Kinderrechtencomité de contouren van een kinderrechtenconform jeugdstrafrechtssysteem op basis van een actuele interpretatie van het Internationaal Verdrag inzake de Rechten van het Kind (IVRK).

Deze bijdrage spitst zich toe op het nieuwe General Comment No. 24 van het Kinderrechtencomité en de mogelijke implicaties daarvan voor het Nederlandse jeugdstrafrecht. General Comment No. 24 is formeel geen juridisch bindend document, maar bevat een gezaghebbende interpretatie van de bepalingen uit het IVRK die betrekking hebben op het jeugdstrafrecht (met name art. 40 en art. 37). Met de ratificatie van het IVRK heeft Nederland zich eraan gecommitteerd om alle passende maatregelen te treffen om de in het verdrag neergelegde rechten van het kind te eerbiedigen en te waarborgen. ${ }^{5}$ General Comment No. 24 biedt concrete aanbevelingen voor de wetgever, beleidsmakers en de

3. VN-Kinderrechtencomité, General Comment No. 24 on children's rights in the child justice system, CRC/C/GC/24, 18 september 2019 (hierna aangeduid als: General Comment No. 24).

4. Zie: VN-Kinderrechtencomité. General Comment No. 10: Children's rights in juvenile justice, CRC/C/GC/10, 25 april 2007 (hierna aangeduid als: General Comment No. 10).

5. Zie art. 4 IVRK. 
rechtspraktijk over hoe deze rechten van het kind effectief kunnen worden geborgd in het jeugdstrafrecht. Het nieuwe General Comment No. 24 is dus zonder meer van belang voor het Nederlandse jeugdstrafrecht. Desalniettemin is het de vraag of de aanbevelingen van het Kinderrechtencomité ook praktisch haalbaar en wenselijk zijn in de Nederlandse context. Deze bijdrage beoogt dit te verkennen en de mogelijke meerwaarde van General Comment No. 24 voor het Nederlandse jeugdstrafrecht te onderzoeken, mede aan de hand van een aantal verkennende interviews dat is afgenomen met professionals uit de jeugdstrafrechtspraktijk.

Voortbouwend op een eerdere bijdrage waarin specifiek aandacht is besteed aan de mogelijke implicaties van General Comment No. 24 voor vrijheidsbeneming van jeugdigen in het Nederlandse jeugdstrafrecht, ${ }^{6}$ worden in de onderhavige bijdrage twee andere specifieke onderdelen van het jeugdstrafrecht uitgelicht: (1) de minimumleeftijdsgrens voor jeugdstrafrechtelijke aansprakelijkheid, en (2) 'diversion', ofwel buitengerechtelijke afdoening van jeugdstrafzaken. Deze thema's zijn geselecteerd, omdat het speerpunten zijn van het nieuwe General Comment No. 24 én het Nederlandse jeugdstrafrecht op deze gebieden nog niet lijkt te voldoen aan de aanbevelingen die het Kinderrechtencomité formuleert om een kinderrechtenconforme jeugdstrafrechtspleging te garanderen. Deze bijdrage beoogt de discussie over de implementatie van deze aanbevelingen in het Nederlandse jeugdstrafrecht in gang te zetten. Uiteindelijk beoogt deze bijdrage ook in bredere zin te reflecteren op de potentiële meerwaarde van het IVRK en General Comment No. 24 voor het Nederlandse jeugdstrafrecht. Alvorens hiertoe over te gaan, worden eerst de meest relevante bepalingen uit het IVRK en de hoofdlijnen van General Comment No. 24 beknopt uiteengezet.

\section{Het IVRK en het jeugdstrafrecht}

General Comment No. 24 betreft een algemeen commentaar van het Kinderrechtencomité dat onlosmakelijk is verbonden met het IVRK. Het Kinderrechtencomité ontleent zijn gezag direct aan het IVRK (art. 43 en 44) en de aanbevelingen die het Comité in General Comment No. 24 doet, zijn rechtstreeks gebaseerd op (zijn gezaghebbende interpretaties van) de voor het jeugdstrafrecht relevante bepalingen uit het IVRK. General Comment No. 24 moet dan ook altijd in samenhang worden gelezen en gebruikt met het IVRK, met name de artikelen 40 en 37.

6. Y.N. van den Brink \& E.M. Mijnarends, 'General Comment No. 24 en het Nederlandse jeugdstrafrecht. Reflecties op vrijheidsbeneming van minderjarigen', in: E.C.C. Punselie e.a. (red.), 30 jaar IVRK, Deventer: Kluwer 2020 (nog te verschijnen) (hierna aangeduid als: Van den Brink \& Mijnarends 2020).
Artikel 40 IVRK is de kernbepaling als het gaat om de rechten van kinderen in het jeugdstrafrecht. ${ }^{7}$ Het eerste lid van deze bepaling formuleert de primaire doelstelling van een kinderrechtenconform jeugdstrafrecht, hetgeen kort gezegd neerkomt op de succesvolle re-integratie van de jeugdige in de samenleving, waarmee ook recidive wordt voorkomen. Het tweede lid bepaalt voorts dat jeugdige verdachten recht hebben op een eerlijk proces en op diverse waarborgen die dit moeten garanderen. Artikel 40 lid 3 IVRK schrijft vervolgens voor dat verdragsstaten een afzonderlijk jeugdstrafrechtssysteem moeten ontwikkelen, waarbij moet worden voorzien in een minimumleeftijdsgrens voor jeugdstrafrechtelijke aansprakelijkheid (onder a) en in mechanismen om strafbare feiten die worden gepleegd door jeugdigen buitengerechtelijk c.q. buitenstrafrechtelijk af te doen (onder b). Het vierde lid van artikel 40 IVRK bepaalt voorts dat jeugdstrafrechtelijke interventies proportioneel moeten zijn ten opzichte van zowel de ernst van het gepleegde strafbare feit, als de omstandigheden van de jeugdige.

Ook artikel 37 IVRK is van bijzonder belang voor kinderen in het jeugdstrafrecht. ${ }^{8}$ Artikel 37 onder a IVRK beschermt jeugdigen tegen onmenselijke en vernederende straffen, waaronder levenslange gevangenisstraffen zonder mogelijkheid tot vervroegde invrijheidstelling. Voorts bepaalt artikel 37 onder b IVRK dat vrijheidsbeneming van jeugdigen slechts als uiterste maatregel en voor de kortst mogelijke passende duur mag worden toegepast. Indien een jeugdige toch van zijn vrijheid is beroofd, heeft hij recht op een verblijf gescheiden van volwassen gedetineerden en op een behandeling die past bij zijn leeftijd en ontwikkelingsfase (art. 37 onder c IVRK). Daarnaast heeft een jeugdige wiens vrijheid is ontnomen, het recht om de legaliteit van de vrijheidsbeneming aan te vechten voor de rechter en daarbij te worden bijgestaan door een raadsman (art. 37 onder $\mathrm{d}$ IVRK).

In General Comment No. 24 doet het Kinderrechtencomité op basis van deze kernbepalingen, die in samenhang moeten worden gelezen met de algemene beginselen ${ }^{9}$ en de overige bepalingen van het IVRK, concrete

7. Zie hierover: E.M. Mijnarends, Richtlijnen voor een verdragsconforme jeugdstrafrechtspleging, 'gelijkwaardig maar minderiarig' (diss. Leiden), Deventer: Kluwer Rechtswetenschappelijke Publicaties 1999; G. van Bueren, Article 40. Child Criminal Justice. A Commentary on the United Nations Convention on the Rights of the Child, Leiden/Boston: Martinus Nijhoff Publishers 2006; T. Liefaard, 'Juvenile justice from an international children's rights perspective', in: W. Vandenhole, E. Desmet, D. Reynaert \& S. Lembrechts (red.), Routledge International Handbook of Children's Rights Studies, Londen: Routledge 2015, p. 234-256.

8. Zie hierover: W. Schabas \& H. Sax, Article 37, Prohibition of Torture, Death Penalty, Life Imprisonment and Deprivation of Liberty. A Commentary on the United Nations Convention on the Rights of the Child, Leiden: Martinus Nijhoff Publishers 2006; T. Liefaard, Deprivation of Liberty of Children in Light of International Human Rights Law and Standards (diss. Amsterdam VU), Antwerpen: Intersentia 2008; Y.N. van den Brink, Voorlopige hechtenis in het Nederlandse jeugdstrafrecht. Wet en praktijk in het licht van internationale en Europese kinder- en mensenrechten (diss. Leiden), Deventer: Kluwer 2018.

9. De algemene beginselen van het IVRK betreffen het non-discriminatiebeginsel (art. 2), het 'belang van het kind' (art. 3), het recht op leven en ontwikkeling (art. 6) en het recht om te worden gehoord (art. 12). 
aanbevelingen voor de ontwikkeling van een kinderrechtenconform jeugdstrafrechtssysteem.

\section{General Comment No. $24^{10}$}

General Comment No. 24 is het resultaat van een herziening van General Comment No. 10 (2007), dat voorheen voorzag in een commentaar op de voor het jeugdstrafrecht relevante bepalingen uit het IVRK. Volgens het Kinderrechtencomité was deze herziening noodzakelijk om het General Comment recht te laten doen aan de ontwikkelingen die zich sinds 2007 hebben voorgedaan op terrein van het jeugdstrafrecht. Het Comité wijst hierbij onder meer op de uitbreiding van kinderrechtenstandaarden op internationaal en regionaal niveau, nieuwe kennis over de ontwikkeling van kinderen en adolescenten en nieuw wetenschappelijk bewijs voor effectieve praktijken in het jeugdstrafrecht. ${ }^{11} \mathrm{Na}$ een open consultatieronde, waarbij maar liefst 65 inhoudelijke reacties op de concepttekst werden ingediend door overheden (waaronder de Nederlandse), non-gouvernementele organisaties en academische instellingen, ${ }^{12}$ heeft het Kinderrechtencomité in september 2019 de finale tekst van General Comment No. 24 vastgesteld en gepubliceerd.

Het Kinderrechtencomité stelt in General Comment No. 24 voorop dat kinderen fundamenteel verschillen van volwassenen in hun fysieke en psychologische ontwikkeling en daarom ook anders moeten worden behandeld als zij de wet overtreden. Verdragsstaten moeten voorzien in een apart jeugdstrafrechtsysteem, waarin de verminderde verwijtbaarheid van kinderen wordt erkend, een op het individuele kind toegesneden aanpak wordt gehanteerd en de rechten van het kind, zoals neergelegd in het IVRK, worden gerespecteerd. ${ }^{13}$ Hierbij onderkent het Comité dat de bescherming van de veiligheid in de samenleving een legitiem doel is van het jeugdstrafrecht, maar dat het nastreven hiervan verdragsstaten niet ontslaat van hun verplichting om de rechten van het kind te respecteren en te beschermen, ook als het gaat om kinderen die een (ernstig) strafbaar feit hebben gepleegd. ${ }^{14}$ Voorts benadrukt het Kinderrechtencomité dat verdragsstaten, die een hoger beschermingsniveau bieden voor de rechten van kinderen in het jeugdstrafrecht dan het IVRK en het General Comment No. 24 strikt genomen eisen, dit beschermingsniveau niet naar beneden mogen brengen (zie art. 41 IVRK). ${ }^{15}$

De in deze paragraaf weergegeven algemene beschrijving van het nieuwe General Comment No. 24 is tevens verwerkt in Van den Brink \& Mijnarends 2020.

11. General Comment No. 24, par. 1.

12. Zie: www.ohchr.org/EN/HRBodies/CRC/Pages/DraftGC10.aspx.

13. General Comment No. 24, par. 2.

14. General Comment No. 24, par. 3.

15. General Comment No. 24, par. 4
$\mathrm{Na}$ de inleidende opmerkingen over de achtergrond en speerpunten van General Comment No. 24 en de uitleg van de gehanteerde terminologie, ${ }^{16}$ zet het Kinderrechtencomité de 'kernelementen' van een kinderrechtenconform jeugdstrafrechtssysteem uiteen. Hierbij besteedt het Comité achtereenvolgens aandacht aan (1) preventie van jeugdcriminaliteit, inclusief vroegtijdige interventies voor kinderen onder de minimumleeftijd voor jeugdstrafrechtelijke aansprakelijkheid, interventies voor kinderen boven de minimumleeftijd voor jeugdstrafrechtelijke aansprakelijkheid, (3) leeftijdsgrenzen in het jeugdstrafrecht, (4) waarborgen voor een eerlijk proces, (5) afdoeningen van jeugdstrafzaken, waaronder zowel buitengerechtelijke als gerechtelijke afdoeningen, (6) vrijheidsbeneming van kinderen, inclusief voorarrest en vrijheidsstraffen, en ten slotte (7) enkele specifieke onderwerpen, waaronder (i) kinderen in militaire rechtbanken, (ii) de aanpak van kinderen die zijn gerekruteerd door non-gouvernementele gewapende groepen, inclusief terroristische organisaties, en (iii) de verhouding tussen het formele jeugdstrafrecht en informele rechtssystemen. ${ }^{17}$ Voorts geeft het Kinderrechtencomité richtlijnen voor de institutionele inrichting en organisatie van een kinderrechtenconform jeugdstrafrechtssysteem en aanbevelingen met betrekking tot de training van professionals en dataverzameling, evaluatie en onderzoek op het gebied van het jeugdstrafrecht. ${ }^{18}$

Het Kinderenrechtencomité neemt in het nieuwe General Comment No. 24 op veel onderdelen geen fundamenteel andere positie in ten opzichte van General Comment No. 10. Toch bevat General Comment No. 24 wel degelijk vernieuwingen, zowel redactioneel als inhoudelijk. Het Comité zet in het nieuwe General Comment expliciet in op het bevorderen van niet-stigmatiserend taalgebruik als het gaat om kinderen die worden verdacht van, of zijn veroordeeld voor het plegen van een strafbaar feit. Dit heeft er onder meer toe geleid dat het Comité in de Engelstalige versie van General Comment No. 24 niet langer spreekt over 'juveniles' en 'juvenile justice', maar in plaats daarvan over 'children' en 'child justice', vanwege de negatieve connotatie die in veel Engelstalige landen kleeft aan het woord 'juvenile' (lees: 'probleemjongere'). ${ }^{19}$

Inhoudelijk springt met name de herziene positie van het Kinderrechtencomité ten aanzien van de minimumleeftijdsgrens voor jeugdstrafrechtelijke aansprakelijkheid in het oog (zie hierover onderstaande par. 4.1). Het Kinderrechtencomité formuleert het waarborgen van een bij de ontwikkeling van kinderen passende minimumleeftijd voor jeugdstrafrechtelijke aansprakelijkheid ook expliciet als één van de inhoudelijke speerpunten van General Comment No. 24. ${ }^{20}$ Een ander speerpunt dat het Comité noemt, is het stimuleren van het gebruik

16. General Comment No. 24, par. 6-8.

17. General Comment No. 24, par. 9-104.

18. General Comment No. 24, par. 105-115.

19. General Comment No. 24, par. 7-8.

20. General Comment No. 24, par. 6. 
van effectieve vormen van 'diversion' om jeugdstrafzaken buitengerechtelijk, dan wel buiten het formele strafrecht af te doen (zie par. 4.2). Voorts noemt het Comité het terugdringen van het gebruik van vrijheidsbeneming van jeugdigen als een belangrijk speerpunt. In de exceptionele gevallen waarin vrijheidsbeneming van jeugdigen toch gerechtvaardigd is als uiterste maatregel, dient volgens het Comité te worden gewaarborgd dat dit enkel 'oudere' jeugdigen betreft en dat de vrijheidsbeneming slechts voor een zo kort mogelijke passende duur wordt toegepast. Een laatste speerpunt dat het Comité uitdrukkelijk noemt in General Comment No. 24 is de wereldwijde uitbanning van de doodstraf, lijfstraffen en levenslange gevangenisstraffen voor kinderen. ${ }^{21}$

Uiteindelijk heeft het nieuwe General Comment No. 24 tot doel om te voorzien in een up-to-date interpretatie van het IVRK en bij te dragen aan een holistische en effectieve implementatie van de bepalingen uit het IVRK in nationale jeugdstrafrechtssystemen, waardoor de schadelijke effecten van het strafrecht voor minderjarigen zoveel mogelijk worden beperkt en dat zij worden behandeld in overeenstemming met hun leeftijd en ontwikkelingsfase. ${ }^{22}$

\section{Reflecties op het Nederlandse jeugdstrafrecht}

De vraag wat de mogelijke implicaties zijn van het nieuwe General Comment No. 24 voor het Nederlandse jeugdstrafrecht is veelomvattend, angezien het Kinderrechtencomité een grote hoeveelheid aanbevelingen doet, die veel verschillende onderdelen van het jeugdstrafrecht betreffen. Het Nederlandse jeugdstrafrecht lijkt op diverse onderdelen niet te voldoen aan de aanbevelingen van het Kinderrechtencomité en daarmee niet volledig IVRK-conform te zijn, bijvoorbeeld als het gaat om het criminaliseren van statusdelicten (vgl. leerplichtzaken), ${ }^{23}$ toepassing van volwassenenstrafrecht ten aanzien van minderjarigen, ${ }^{24}$ het beleid en de praktijk inzake justitiële documentatie en Verklaringen Omtrent het Gedrag bij jeugdigen, ${ }^{25}$ alsook het gebruik van vrijheidsbeneming in jeugdstrafzaken, in het bijzonder het verblijf van minderjarigen in politiecellen. ${ }^{26}$ In deze bij-

21. General Comment No. 24, par. 6.

22. General Comment No. 24, par. 6

23. Vgl. D.I. van Weerden, 'Strafrecht te-recht?! De inzet van het jeugdstrafrecht voor de handhaving van de leerplicht in kinderrechtenperspectief', FJR 2018/17, p. 73-79.

24. Art. 77b Sr. Vgl. VN-Kinderrechtencomité, Concluding observations on the fourth periodic report of the Netherlands (CRC/C/NDL/CO/4), 8 juni 2015, par. 58.

25. Vgl. E.G. van 't Zand-Kurtovic, 'Dutch Criminal Record Screening in Light of International Children's Rights Standards', in: S. Meijer, H. Annison \& A. O'Loughlin (red.), Fundamental Rights and Legal Consequences of Criminal Conviction, Oxford: Hart Publishing, p. 265-284.

26. Vgl. Raad voor Strafrechtstoepassing en Jeugdbescherming (RSJ), Minderjarigen in een politiecel. Een advies over duur, verblijf en alternatieve locaties, Den Haag, 28 januari 2020. Zie ook: Y.N. van den drage willen wij ons echter specifiek richten op twee andere in het oog springende onderdelen van het Nederlandse jeugdstrafrecht, die niet in overeenstemming zijn met de anbevelingen die het Kinderrechtencomité in General Comment No. 24 doet op basis van zijn interpretatie van het IVRK: (1) de minimumleeftijdsgrens voor jeugdstrafrechtelijke aansprakelijkheid, en (2) het gebruik van 'diversion', ofwel de buitengerechtelijke/buitenstrafrechtelijke afdoening van jeugdstrafzaken. Deze thema's zijn, zoals gezegd, door het Kinderrechtencomité nadrukkelijk geformuleerd als twee van de voornaamste speerpunten van het nieuwe General Comment No. 24.

Om te reflecteren op de wenselijkheid en haalbaarheid van implementatie van de aanbevelingen van het Comité in General Comment No. 24 in het Nederlandse jeugdstrafrecht, is een aantal verkennende interviews afgenomen met professionals uit de jeugdstrafrechtspraktijk, waaronder kinderrechters $(\mathrm{N}=3)$, advocaten $(\mathrm{N}=3)$, officieren van justitie $(\mathrm{N}=2)$, een politieagent en een vertegenwoordiger van Bureau Halt $(\mathrm{N}=1)$. Tijdens de interviews zijn de respondenten concrete aanbevelingen van het Kinderrechtencomité uit General Comment No. 24 voorgelegd en is hen gevraagd daarop te reflecteren op basis van hun ervaringen in de Nederlandse jeugdstrafrechtspraktijk. De afgenomen interviews zijn exploratief van aard en bescheiden in aantal, en vanzelfsprekend niet representatief voor de gehele Nederlandse jeugdstrafrechtspraktijk. Desalniettemin kan aan de hand van de opvattingen van de geinterviewde professionals, die vanuit uiteenlopende rollen dagelijks in deze praktijk werken, een indicatief beeld worden geschetst van de mogelijke implicaties van de aanbevelingen van het Comité in het nieuwe General Comment No. 24 voor het jeugdstrafrecht in Nederland.

\subsection{Minimumleeftijdsgrens voor jeugdstrafrechtelijke aansprakelijkheid}

Op grond van artikel 40 lid 3 onder a IVRK dienen alle verdragsstaten een minimumleeftijdsgrens voor jeugdstrafrechtelijke aansprakelijkheid in de wet op te nemen. Het IVRK geeft echter zelf geen indicatie wat die minimumleeftijd zou moeten zijn. Het Kinderrechtencomité spreekt zich hierover wel uit. In zijn voormalige General Comment No. 10 stelde het Comité zich op het standpunt dat een minimumleeftijd van 12 jaar de absolute ondergrens is en dat een hogere minimumleeftijdsgrens van 14 of 16 wordt aangemoedigd. ${ }^{27}$ In zijn nieuwe General Comment No. 24 is evenwel een verschuiving in de opvatting van het Comité zichtbaar. Hierin roept het Comité verdragsstaten op de minimumleeftijdsgrens voor jeugdstrafrechtelijke aansprakelijkheid te verhogen naar ten minste 14 jaar, waarbij een hogere minimumleeftijd van 15 of 16 jaar wordt angemoedigd. ${ }^{28}$ Hierbij

Brink, 'Kind in de politiecel', FJR 2020/8, p. 31. En voorts: Van den Brink \& Mijnarends 2020.

27. General Comment No. 10, par. 32-33

28. General Comment No. 24, par. 22 
wijst het Comité erop dat de minimumleeftijd van 14 jaar wereldwijd het gemiddelde is (hetgeen overigens feitelijk niet klopt; 14 jaar is wereldwijd de meest voorkomende minimumleeftijdsgrens, maar niet het gemiddelde). Ook stelt het Comité dat recent ontwikkelingspsychologisch onderzoek en hersenonderzoek laat zien dat jeugdigen jonger dan 14 jaar niet goed in staat zijn om de consequenties van hun handelen te overzien en om het strafproces echt te begrijpen. ${ }^{29}$

In Nederland is de minimumleeftijd voor jeugdstrafrechtelijke aansprakelijkheid, zoals bekend, 12 jaar (art. $486 \mathrm{~Sv}$ en art. 77a Sr). Recent heeft deze leeftijdsgrens ter discussie gestaan naar aanleiding van een rapport van de Raad voor Strafrechtstoepassing en Jeugdbescherming (RSJ), waarin werd aanbevolen om de minimumleeftijdsgrens te verhogen naar 14 jaar. ${ }^{30}$ Minister Dekker heeft in zijn beleidsbrief van 28 juni 2019 evenwel duidelijk gemaakt dat geen gehoor wordt gegeven aan deze aanbeveling van de RSJ, waarbij hij als argumenten noemt dat hij de mogelijkheid wil behouden om strafrechtelijk te reageren op 12- en 13-jarigen die ernstige strafbare feiten plegen én dat de minimumleeftijdsgrens van 12 jaar in lijn is met het IVRK. ${ }^{31}$ Dit laatste argument verliest met het verschijnen van General Comment No. 24 echter aanzienlijk aan kracht.

Tegen deze achtergrond is tijdens de interviews aan de respondenten de vraag voorgelegd of Nederland de minimumleeftijdsgrens voor jeugdstrafrechtelijke aansprakelijkheid zou moeten verhogen naar 14 jaar, zoals het Kinderrechtencomité aanbeveelt. Op deze vraag werd door de respondenten uit de jeugdstrafrechtspraktijk wisselend gereageerd. Zo stelt een geïnterviewde officier van justitie dat de minimumgrens wat haar betreft niet zou moeten worden verhoogd, gelet op de ernst van de strafbare feiten die sommige 12- en 13-jarigen plegen.

'Ik zie heel veel kinderen die onder de 14 zijn en heel heftige strafbare feiten plegen. Ik vind het dus ingewikkeld om te zeggen dat dergelijk gedrag onder de 14 jaar nog kwajongensgedrag is waarvoor de ouders verantwoordelijk en aansprakelijk gesteld kunnen worden. Natuurlijk is het zo dat uit hersenonderzoek blijkt dat de hersenen van minderjarigen nog niet volgroeid zijn en hun handelen aan die nog niet voltooide ontwikkeling kan worden toegeschreven, maar als ik zie wat in onze regio voorbij komt, zie ik geen reden om van 12 naar 14 te gaan. ${ }^{32}$

Een geinterviewde kinderrechter staat daarentegen om verschillende redenen niet onwelwillend tegenover de door het Comité aanbevolen verhoging naar 14 jaar. Wel stelt deze kinderrechter dat, voorafgaand aan de

29. General Comment No. 24, par. 22.

30. RSJ, Verhoging strafrechtelijke minimumleeftijd in context. Advies over verhoging van de strafrechtelijke minimumleeftijd en het belang van goede jeugdhulp, Den Haag, 20 december 2017.

31. Kamerstukken I/ 2018/19, 28741, 53.

32. Interview officier van justitie $B$. invoering van een dergelijke verhoging van de minimumleeftijdsgrens, goed moet worden nagedacht over hoe het jeugdbeschermingsrecht moet omgaan met 12en 13-jarigen die (ernstige) strafbare feiten plegen en hoe de waarheidsvinding geborgd blijft.

'Wat betreft die leeftijd van 14 jaar, dan verwijs ik graag naar wat de RSJ daarover in haar rapport heeft gezegd, namelijk dat het best een goed idee is gelet op de hersenontwikkeling bij minderjarigen. Daarnaast zie je dat in het burgerlijk recht dat de aansprakelijkheid bij minderjarigen is vastgesteld op 14 jaar. Gelet op de rechtsdogmatiek in Nederland is dat dus helemaal niet zo raar om 14 jaar te hanteren. Hierbij moet wel opgemerkt worden dat het civiele recht met haar beschermingsmaatregelen niet capabel genoeg is om strafrechtelijk relevante feiten adequaat op te pakken. Dat is de grootste bottleneck. Wat ook ingewikkeld is, is dat je met deze leeftijdsgrens minder goed gaat uitzoeken of een minderjarige verdachte ook de dader is. Als je midden in dat jeugdbeschermingstraject gaat zitten, is de vraag of een minderjarige het feit wel of niet gepleegd heeft minder aan de orde. Zo'n leeftijdsgrens kan dus ook naar zijn. In principe sta ik dus niet onwelwillend tegen de leeftijd van 14 jaar, maar het vraagt wel om heel veel doordenken over de consequenties.' 33

Een geinterviewde medewerker van Bureau Halt stelt evenwel dat het op dit moment zowel politiek als praktisch niet realistisch is om de door het Comité aanbevolen verhoging van de minimumleeftijdsgrens naar 14 jaar door te voeren in Nederland. Wel kan zij zich voorstellen dat het een beleidsvoornemen zou kunnen zijn om de komende jaren richting die minimumleeftijd van 14 jaar te gaan bewegen.

'Gelet op de huidige situatie op het Departement lijkt het mij volstrekt niet haalbaar om die leeftijd naar 14 jaar te verhogen. Daarom proberen we nu vooral aandacht te krijgen om bij de groep 12-14 jaar het concept "geen strafrecht, tenzij..." toe te passen. Ik denk dat dat ook goed is. Als je bij deze groep kinderen helemaal geen strafrecht zou kunnen toepassen, dan kun je ook geen strafrechtelijk onderzoek doen. (...) De mogelijkheid tot waarheidsvinding moet je niet blokkeren. Aan de andere kant zie ik op dit moment geen enkele structuur of kader anders dan het strafrecht dat adequaat genoeg is om de gewenste correctie teweeg te brengen bij bijvoorbeeld 12-jarigen die voortdurend delicten plegen. (...) Politiek lijkt de verhoging mij dus op dit moment onhaalbaar, maar ook praktisch lijkt het mij op dit moment onhaalbaar. Ik kan mij hooguit voorstellen dat je dan een soort beleidsvoornemen voorstelt waarin je uitspreekt dat je over zoveel tijd bij die 14 jaar wilt komen en wat je in de tussentijd daarvoor wilt neerzetten.' $^{34}$

33. Interview kinderrechter A.

34. Interview medewerker Bureau Halt. 
Wat de auteurs van deze bijdrage betreft, zou een dergelijk beleidsvoornemen er moeten komen. Het Kinderrechtencomité noemt fundamentele argumenten waarom de minimumleeftijd voor jeugdstrafrechtelijke aansprakelijkheid niet lager dan 14 jaar zou moeten zijn, die ook door Nederland serieus zouden moeten worden genomen. De groeiende consensus in de wetenschap dat jeugdigen jonger dan 14 jaar niet goed in staat zijn om de gevolgen van hun handelen te overzien en om effectief te participeren in hun eigen strafproces, waardoor ook het recht op een eerlijk proces in gevaar komt, kan niet worden genegeerd. ${ }^{35}$ Tegelijkertijd moet de vraag worden gesteld of het alternatief voor 12- en 13-jarigen die thans met het jeugdstrafrecht in aanraking komen op dit moment beter is. Ook het Kinderrechtencomité erkent het belang van deze vraag, en stelt uitdrukkelijk dat de effectiviteit van een minimumleeftijdsgrens voor jeugdstrafrechtelijke ansprakelijkheid afhangt van de wijze waarop zowel jeugdigen boven als onder die leeftijdsgrens worden behandeld. ${ }^{36}$ Met andere woorden: verhoging van de minimumleeftijdsgrens naar 14 jaar mag geen verslechtering van de situatie van 12 - en 13 jarigen met zich brengen.

Het meest voor de hand liggende alternatief voor het jeugdstrafrecht is om bij jeugdigen van 12- en 13-jarigen die strafbare feiten plegen het jeugdbeschermingsrecht in te zetten, zoals thans ook bij 12-minners gebeurt. Voorafgaand aan een verhoging van een minimumleeftijdsgrens voor jeugdstrafrecht naar 14 jaar, is onzes inziens vereist dat eerst goed wordt onderzocht hoe het jeugdbeschermingsrecht kan worden toegerust met interventies - zonder punitief karakter - die geschikt zijn voor 12- en 13-jarigen die (ernstige) strafbare feiten plegen. Hierbij moet worden nagedacht over hoe de veiligheid van de samenleving, waaronder ook de veiligheid van andere jeugdigen die in jeugdhulpaccommodaties verblijven, kan worden geborgd, alsook hoe herstelrechtelijke interventies - en dus ook slachtoffers - een plaats kunnen krijgen binnen het jeugdbeschermingssysteem. Daarnaast moet aandacht worden besteed aan de versterking van de rechtsbescherming van jeugdigen in het jeugdbeschermingsrecht, die thans over het algemeen minder sterk is dan de rechtsbescherming van jeugdigen in het jeugdstrafrecht.

Voorts verdient ook het belang van de (strafrechtelijke) waarheidsvinding nadere overdenking, bijvoorbeeld de vraag hoe een 12- of 13-jarige die wordt verdacht van een ernstig strafbaar feit, maar zelf ontkent dat hij zich daaraan schuldig heeft gemaakt, zijn recht kan halen ('access to justice'). Bovendien kan het ook voor de slachtoffers belangrijk zijn dat in zaken van verdachten die jonger zijn dan de jeugdstrafrechtelijke minimum-

35. Zie onder meer: I. Weijers, 'The minimum age of criminal responsibility in continental Europe has a solid rational base', Northern Ireland Legal Quarterly 2016, 67(3), p. 301-310; S.E. Rap, The participation of juvenile defendants in the youth court: A comparative study of juvenile justice procedures in Europe (diss. Utrecht), Amsterdam: Pallas publications 2013; T. Doreleijers \& J. Fokkens, 'Minderjarigen en jongvolwassenen: pleidooi voor een evidence based strafrecht', Rechtstreeks 2010/2.

36. General Comment No. 24, par. 23. leeftijd door middel van een grondige rechterlijke procedure wordt uitgezocht wie de schuldige is van het strafbare feit. Om die redenen bestaat bijvoorbeeld in Zweden, waar de minimumleeftijd voor jeugdstrafrechtelijke aansprakelijkheid 15 jaar is, de mogelijkheid om indien de verdachte jonger is dan de minimumleeftijd toch een strafrechtelijke procedure te starten, enkel ten behoeve van de waarheidsvinding, zonder mogelijkheid tot veroordeling van de verdachte. ${ }^{37}$ Ook in Nederland kan bij een verhoging van de minimumleeftijd worden nagedacht over het ontwikkelen van een dergelijke procedure.

Tot slot zou wat ons betreft, in de tussentijd moeten worden nagedacht over de invoering van een hogere minimumleeftijd voor bepaalde vormen van vrijheidsbeneming in het jeugdstrafrecht. Het Kinderrechtencomité moedigt verdragsstaten uitdrukkelijk aan om een minimumleeftijd voor vrijheidsbeneming in te voeren, bijvoorbeeld 16 jaar. ${ }^{38}$ Hoewel een generiek verbod op elke vorm van vrijheidsbeneming van jeugdigen onder 16 in het jeugdstrafrecht onzes inziens niet houdbaar is (dit zou immers betekenen dat 15 -jarigen die delicten plegen niet eens kunnen worden aangehouden en opgehouden voor verhoor), zou wat ons betreft wel serieus moeten worden nagedacht over de invoering van een aparte minimumleeftijdsgrens voor vormen van vrijheidsbeneming die evident ongeschikt zijn voor (jonge) minderjarigen, zoals het verblijf in een reguliere 'kale' politiecel. Denkbaar is bijvoorbeeld om voor 12- en 13jarigen eenzelfde termijn voor ophouden voor verhoor te laten gelden als thans voor 12-minners geldt (lees: maximaal zes uur; art. 487 lid $2 \mathrm{~Sv}$ ) en dat aangehouden jeugdigen jonger dan 14 jaar altijd in een zogenoemde 'kindvriendelijke cel' moeten verblijven. ${ }^{39}$

\section{2. 'Diversion': buitengerechtelijke/ buitenstrafrechtelijke afdoening}

Op grond van artikel 40 lid 3 onder b IVRK dienen verdragsstaten te voorzien in mechanismen om strafbare feiten die zijn gepleegd door jeugdigen buitengerechtelijk, dan wel buitenstrafrechtelijk af te doen, mits de rechten van het kind en de wettelijke garanties daarbij onverkort worden gewaarborgd. Deze afdoeningsvormen worden ook wel aangeduid als 'diversion', hetwelk door het Kinderrechtencomité - vrij vertaald - wordt gedefinieerd als het afbuigen van jeugdstrafzaken, weg van het formele jeugdstrafrechtsysteem, op elk moment voorafgaand aan, of tijdens de procedure. ${ }^{40}$ Volgens het

Deze procedure wordt in Zweden aangeduid als 'bevistalan'.

General Comment No. 24, par. 89

Zie hierover: Van den Brink \& Mijnarends 2020. Vgl. ook: RSJ, Minderjarigen in een politiecel. Een advies over duur, verblijf en alternatieve locaties, Den Haag, 28 januari 2020.

40. General Comment No. 24, par. 6(c), 8 en 15. 'Diversion' laat zich evenwel lastig vertalen naar het Nederlands. De term 'buitengerechtelijke afdoening' benadrukt dat 'diversion' beoogt de schadelijke gevolgen van een formele gerechtelijke procedure bij jeugdigen te voorkomen, maar doet niet geheel recht aan het standpunt van het Comité dat 'diversion' op elk moment van de procedure mogelijk moet zijn, ook nog ter zitting door de rechtbank. De term 'buitenstrafrechtelijke afdoening' benadrukt weliswaar dat 'diversion' beoogt de nadelige gevolgen van een formele strafrechtelijke afdoening (bijvoorbeeld het verkrijgen 
Comité zijn mogelijkheden tot 'diversion' om meerdere redenen van belang voor een kinderrechtenconforme jeugdstrafrechtspleging. Zo kan 'diversion' de stress en schade van een langdurig gerechtelijk strafproces voor jeugdigen voorkomen, evenals de stigmatisering die uitgaat van een strafrechtelijke afdoening en van justitiële documentatie. $^{41}$ Volgens het Comité zou 'diversion' moeten worden toegepast in de meerderheid van de jeugdstrafzaken. ${ }^{42}$

Toepassing van 'diversion' moet echter wel gepaard gaan met eerbiediging van de rechten die jeugdige verdachten op grond van het IVRK toekomen, waaronder het recht op een eerlijk proces en toegang tot de rechter. ${ }^{43}$ Het Kinderrechtencomité voorziet daarom in General Comment No. 24 in een opsomming van voorwaarden waaraan 'diversion' zou moeten voldoen. ${ }^{44} \mathrm{Zo}$ mag 'diversion' enkel worden toegepast als sprake is van overtuigend bewijs dat de jeugdige zich schuldig heeft gemaakt aan een strafbaar feit en als de betreffende jeugdige vrijwillig (lees: zonder pressie) een bekentenis aflegt en verantwoordelijkheid neemt. Ook is voor 'diversion' vrije en goed geïformeerde instemming van de jeugdige vereist, waarbij de jeugdige het recht heeft op juridische of andere passende bijstand. Verder moet 'diversion' van jeugdstrafzaken een wettelijke basis hebben, moet de besluitvorming daaromtrent gereguleerd en toetsbaar zijn, en moeten de betrokken professionals daarin zijn getraind. Voorts mag 'diversion' volgens het Comité nooit vrijheidsbeneming van de jeugdige tot gevolg hebben. Tot slot moet 'diversion' resulteren in de onherroepelijke afdoening van de jeugdstrafzaak, waarbij het succesvol doorlopen van het 'diversion'-programma voorkomt dat de jeugdige een strafblad krijgt. ${ }^{45}$

In Nederland is de OM-afdoening, in het bijzonder de transactie, een veelgebruikte vorm van buitengerechtelijke afdoening van jeugdstrafzaken, ${ }^{46}$ maar deze afdoeningsvorm kan desalniettemin in zijn huidige vorm niet worden gekwalificeerd als een vorm van 'diversion' zoals het Comité dat voor ogen heeft. De OM-afdoening is immers wel degelijk een strafrechtelijke afdoening, die ook resulteert in een aantekening in de justitiële documentatie, en in de weg kan staan aan het verkrijgen van een Verklaring Omtrent het Gedrag. De Halt-afdoening kan daarentegen wel worden aangeduid als een vorm van 'diversion' en lijkt ook te voldoen aan alle eisen die

van een strafblad) te voorkomen, maar doet geen recht aan het feit dat veel 'diversion'-programma's (zoals Halt in Nederland) wel onderdeel uitmaken van het formele jeugdstrafrecht. Om deze reden wordt in het vervolg de term 'diversion' gebruikt.

41. General Comment No. 24, par. 6 en 15

42. General Comment No. 24, par. 16.

43. Art. 40 lid 3 onder b IVRK jo. art. 40 lid 2 IVRK. Zie ook: General Comment No. 24, par. 16 en 18

44. General Comment No. 24, par. 18

45. General Comment No. 24, par. 18.

46. De OM-strafbeschikking is nog niet geïmplementeerd in de jeugdstrafrechtspraktijk. het Comité daaraan stelt. ${ }^{47}$ De Halt-afdoening wordt veelvuldig toegepast en was in 2018 goed voor de afdoening van naar schatting ruim een derde van alle misdrijfzaken van jeugdigen in Nederland. ${ }^{48}$ Wel blijft de toepassing van de Halt-afdoening doorgaans beperkt tot de vroege voorfase van het strafproces (direct na de aanhouding of via de ZSM-tafel), ${ }^{49}$ terwijl het Kinderrechtencomité stelt dat 'diversion' gedurende de verschillende stadia van het strafproces mogelijk zou moeten blijven. ${ }^{50}$ Ook beperkt Halt zich in beginsel tot de afdoening van strafbare feiten van geringe ernst. ${ }^{51}$ Het Kinderrechtencomité moedigt verdragsstaten evenwel aan om de strafbare feiten waarvoor 'diversion' mogelijk is, uit te breiden, waarbij ook zware strafbare feiten niet bij voorbaat zouden moeten worden uitgesloten. ${ }^{52}$ Het is dus de vraag of het Nederlandse jeugdstrafrecht met enkel de Halt-afdoening in zijn huidige vorm, voldoende tegemoetkomt aan de aanbevelingen van het Kinderrechtencomité over het stimuleren van 'diversion' in jeugdstrafzaken.

Tijdens de interviews is aan professionals uit de jeugdstrafrechtspraktijk de vraag voorgelegd of de strafbare feiten die in aanmerking komen voor 'diversion', zouden moeten worden uitgebreid. Een geinterviewde advocaat ziet daartoe mogelijkheden, niet zozeer binnen de Haltafdoening, maar eerder in de hervorming van de OMafdoening.

'Op dit moment geldt Halt alleen voor de kleine feiten. Ik vind ook niet dat alle feiten voor Halt open zouden moeten staan. Als je 'diversion' wilt uitbreiden, moet je denk ik naar een nieuw systeem gaan, dat passend is voor andere feiten. Zo zou je bijvoorbeeld de OM-zitting buiten het strafrecht kunnen trekken.' 53

Voorts is ook tijdens de interviews besproken of de mogelijkheid tot 'diversion' gedurende het gehele proces prominenter aanwezig zou moeten zijn, dus ook in een later stadium, bijvoorbeeld vlak voor of tijdens de OMzitting of zitting bij de rechter. De officier van justitie kan weliswaar nu ook in een later stadium alsnog besluiten om een zaak naar Halt te verwijzen, maar dit lijkt geen vaste praktijk te zijn. Een geïnterviewde kinderrechter toont zich groot voorstander van het verder ontwikkelen van de mogelijkheid tot 'diversion' in een later stadium van de strafrechtelijke procedure, in het bijzonder vanwege de ontwikkelingsfase waarin jeugdigen zich bevinden.

47. Vgl. art. 77e Sr en Richtlijn en kader voor strafvordering jeugd en adolescenten, inclusief strafmaten Halt (2018R007), '4.2 Halt'.

48. In 2018 werden 7100 misdrijfzaken van jeugdigen via Halt afgedaan Zie: R. Choenni, S.W. van den Braak \& P.F.M. Platenburg (red.), 'Criminaliteit en rechtshandhaving 2018', Cahier 2019/16.

49. Alhoewel in sommige gevallen ook de officier van justitie tijdens de OM-afdoening kan besluiten de zaak alsnog naar Halt te verwijzen. Vgl. art. 2 Besluit aanwijzing Halt-feiten.

50. General Comment No. 24, par. 16.

51. Zie Besluit aanwijzing Halt-feiten.

52. General Comment No. 24, par. 16.

53. Interview advocaat $\mathrm{C}$. 
'Daar ben ik een voorstander van. Stel dat een puber net is opgepakt. Die zit nog helemaal in de verzetstand. Die is er helemaal nog niet aan toe om verantwoordelijkheid te nemen. (...) Het kost [voor een puber] tijd om dingen te snappen. Ik ben er dus hartstikke voor dat die mogelijkheid er komt. Je weet dan ook veel meer hoe iemand erin staat, of hij meewerkt, of hij open staat voor behandeling, hoe hij om is gegaan met het slachtoffergesprek. Van mij mag het slachtoffer daar ook een rol in spelen. Geen beslissende rol, maar je mag hem er wel bij betrekken. Als een slachtoffer nu zegt: "kijkend naar wat er is gebeurd, vind ik het goed zo, want mijn schade is vergoed, ik heb een gesprek gehad, die jongen heeft dit en dat gedaan...." Wie ben jij dan als overheid om te zeggen "nee, die jongen gaat toch naar de zitting toe"? (...) Ik ben daar dus hartstikke voor. ${ }^{54}$

Een andere geinterviewde kinderrechter toont zich groot voorstander van de invoering van de mogelijkheid dat ook de rechter jeugdstrafzaken ambtshalve via 'diversion' (bijvoorbeeld Halt of een civielrechtelijke maatregel) mag afdoen.

'Dat vind ik wenselijk en haalbaar, ook omdat je als rechter een andere bril hebt dan de officier van justitie. Je kijkt vanuit een ander perspectief. En soms kristalliseert een en ander zich ook later uit. Ik heb een zaak gehad van een jongen die zijn stiefvader had geslagen en bedreigd, maar later bleek dat in dat gezin van die jongen er meer aan de hand was; dat delict stond niet op zichzelf. Het was dan ook niet zozeer de fout van die jongen, maar de zaak staat wel op zitting. Ik kan dan weinig anders dan een beslissing nemen. Het zou mooi zijn als dan ter zitting de zaak naar Halt verwezen kon worden. Daarbij zou het ook heel fijn zijn als je als strafrechter een civielrechtelijke maatregel kunt opleggen. Sommige zaken horen gewoon niet in het strafrecht thuis. ${ }^{55}$

Ook wat de auteurs van deze bijdrage betreft, verdient de anbeveling van het Comité tot uitbreiding van de mogelijkheden tot 'diversion' in het Nederlandse jeugdstrafrecht serieuze overweging. In anvulling op de thans bestaande Halt-afdoening, zou het OM de mogelijkheid kunnen krijgen om ook zaken waarin het gaat om ernstigere strafbare feiten (lees: niet-Haltwaardige zaken) af te doen door bijvoorbeeld jeugdreclasseringsbegeleiding, een behandeling en/of een taakstraf op te leggen, maar zonder dat dit resulteert in wat in de volksmond een strafblad heet. Ook de kinderrechter zou een actievere rol kunnen krijgen in het gebruik van 'diversion', zoals ook in andere landen gebruikelijk is. Zo worden bijvoorbeeld zittingen in Britse youth courts geregeld door de kinderrechter voor een paar weken aangehouden, met de instructie aan de officier van justitie om alsnog een buitenstrafrechtelijke afdoening te

54. Interview kinderrechter B.

55. Interview kinderrechter $C$. overwegen. Ook beschikt de Britse youth court over de mogelijkheid om bij bekennende first-offenders een zogenoemde 'referral order' op te leggen, een gemeenschapsgeoriënteerde maatregel die een aantal maanden van toezicht en begeleiding, en deelname aan leerprojecten en andere herstelgerichte interventies kan inhouden. Hoewel de 'referral order' wel resulteert in een aantekening in de justitiële documentatie, hoeft deze maatregel na een succesvolle afronding bij sollicitaties niet te worden geopenbaard aan potentiële werkgevers. ${ }^{56}$ Het is onzes inziens het onderzoeken waard of een actievere rol van de kinderrechter bij 'diversion' ook in het Nederlandse jeugdstrafrecht zou passen.

Tot slot is het, mede gelet op de huidige beleidsontwikkelingen in Nederland, van belang om nogmaals te benadrukken dat de aanbeveling van het Kinderrechtencomité om 'diversion' te stimuleren geenszins mag worden opgevat als een legitimatie om door het stimuleren van informele, buitengerechtelijke afdoeningen fundamentele waarborgen van het jeugdstrafrecht te omzeilen, waaronder het recht op een eerlijk proces en toegang tot de rechter. De aanbevelingen van het Comité zijn dan ook geenszins een vrijbrief voor politici en beleidsmakers om de rechtspraak en de gefinancierde rechtsbijstand (verder) uit te kleden.

\section{General Comment No. 24 - nieuw elan voor het Nederlandse jeugdstrafrecht?}

In deze bijdrage hebben wij de hoofdlijnen van het nieuwe General Comment No. 24 uiteengezet. Vervolgens hebben wij de daarin neergelegde interpretaties en aanbevelingen van het Kinderrechtencomité als basis gebruikt om, aan de hand van interviews met professionals uit de jeugdstrafrechtspraktijk, twee belangrijke onderdelen van het Nederlandse jeugdstrafrecht kritisch tegen het licht te houden: de minimumleeftijdsgrens voor jeugdstrafrechtelijke ansprakelijkheid en het gebruik van 'diversion'. In deze slotparagraaf proberen wij deze specifieke thema's te ontstijgen en te reflecteren op de potentiële meerwaarde van het IVRK en General Comment No. 24 voor het Nederlandse jeugdstrafrecht in bredere zin.

De meerwaarde van het nieuwe General Comment No. 24 is wat ons betreft allereerst gelegen in het feit dat het Kinderrechtencomité hiermee voorziet in een actuele en gezaghebbende interpretatie van het IVRK; een verdrag waaraan Nederland ook in het kader van het jeugdstrafrecht gebonden is. De anbevelingen van het Kinderrechtencomité zijn bovendien niet alleen gebaseerd op de bepalingen uit het IVRK, maar ook op wetenschap- 
pelijke inzichten en 'good practices' uit andere verdragsstaten. Voorbeelden van aanbevelingen die steun vinden in bestaande nationale jeugdstrafrechtssystemen, zijn de hogere minimumleeftijdsgrens voor bepaalde vormen van vrijheidsbeneming (zoals bijvoorbeeld in Zwitserland geldt), alsook de mogelijkheid tot 'diversion' door de kinderrechter ter zitting (vgl. de bovengenoemde Britse praktijken). Hiermee voorziet het nieuwe General Comment No. 24 in een gefundeerd instrument om kritisch te reflecteren op het Nederlandse jeugdstrafrecht en daarbij ook over de eigen landsgrenzen te kijken.

Voorts zijn het IVRK en General Comment No. 24 niet alleen bruikbaar op wetgevings- en beleidsniveau, maar ook voor individuele professionals in de jeugdstrafrechtspraktijk, waaronder rechters, officieren van justitie en advocaten, alsook professionals die werkzaam zijn bij de Raad voor de Kinderbescherming, jeugdreclassering, justitiële jeugdinrichtingen of de politie. Het IVRK en General Comment No. 24 kunnen als houvast en als kompas dienen bij besluitvorming binnen de jeugdstrafrechtsketen. Zo bieden zij een krachtig kader om tegenwicht te bieden tegen de politieke en maatschappelijke roep om jeugdigen harder te straffen, nu het kinderrechtenkader juridische en praktische waarde geeft aan het uitgangspunt dat jeugdige verdachten en veroordeelden eerst en vooral kinderen zijn, en dat de maatschappij uiteindelijk het meest gebaat is bij hun succesvolle re-integratie in de samenleving. Ook voorzien het IVRK en General Comment No. 24 in een stevig kader om tegenwicht te bieden tegen al te paternalistische tendensen in het jeugdstrafrecht, nu het kinderrechtenkader overtuigend promoot dat kinderen niet louter beschermingsobjecten, maar rechtssubjecten zijn en dat het 'belang van het kind' niet mag worden gebruikt als legitimatie om fundamentele rechten van kinderen, zoals het recht op een eerlijk proces, te negeren. ${ }^{57}$

Uiteindelijk hangt de meerwaarde van het IVRK en General Comment No. 24 echter af van de vraag of en hoe deze instrumenten worden gebruikt door de wetgever, beleidsmakers en in de rechtspraktijk. Ondanks dat het IVRK inmiddels ruim 30 jaar bestaat en al 25 jaar geldend recht is in Nederland, ${ }^{58}$ spelen het IVRK en met name General Comments nog altijd een vrij marginale rol in het Nederlandse jeugdstrafrecht. Het is wat ons betreft dan ook hoog tijd dat de professionele actoren die zich bezighouden met het jeugdstrafrecht, in het bijzonder de rechtspraktijk, actiever en explicieter gebruik gaan maken van het IVRK en General Comment No. 24. Slechts dan bieden deze kinderrechtelijke instrumenten daadwerkelijk rechtsbescherming aan jeugdigen en kunnen zij daadwerkelijk nieuw elan geven aan de Nederlandse jeugdstrafrechtspleging.

57. Zie hierover ook: Y.N. van den Brink, 'Young, Accused and Detained Awful, But Lawful? Pre-Trial Detention and Children's Rights Protection in Contemporary Western Societies', Youth Justice 2019, 19(3), p. 238-261.

58. Zie Rijkswet van 24 november 1994, Stb. 1994, 862. Het IVRK is in Nederland op 8 maart 1995 in werking getreden.

\section{Children}

3

'Fimmy was about eight years old when put to work in the factory: given a stick and a piece of maste and shown how to use it.

He mas at mork upon a machine, cleaning out trash that had accumulated in the cogmheels, when he mas injured.

In a spirit of playfulness he would manipulate the cogmheeels; although as a judge mas to say, the boy had been repeatedly "advised" by other employees and even by the assistant superintendent of the company -

as to the danger

of "a negligent attention to his business"., 59
59. Charles Reznikoff, Testimony. The United States (1885-1915): Recitative, Boston: Black Sparrow 2015, p. 119-120. Reznikoff heeft in de archieven de processtukken bestudeerd van Amerikaanse rechtszaken over de jaren 1885-1915, zowel civiel als strafrecht. Hij brengt in zijn gedichten de feiten en omstandigheden die redengevend waren voor de beslissing tot de kern terug. 